\title{
Clearance half life of mercury in urine after the cessation of long term occupational exposure: influence of a chelating agent (DMPS) on excretion of mercury in urine
}

\author{
Gerd Sällsten, Lars Barregård, Andrejs Schütz
}

\begin{abstract}
The elimination of mercury $(\mathrm{Hg})$ in urine was investigated in 12 former chloralkali workers exposed to metallic $\mathrm{Hg}$ vapour for two to 18 (median five) years. Morning urine samples were taken on several (median 9) occasions after change of employment or retirement. The median follow up time was 28 months. The decrease in concentration of $\mathrm{Hg}$ in urine (U-Hg) was well characterised by a one compartment model. Three different regression methods were used; non-linear least squares regression (NLSR), weighted non-linear least squares regression (WNLSR), and linear least squares regression (LLSR) after log transformation of the U-Hg data. The median half life from the WNLSR method was 55 days. There were no large differences in the half life estimates given by the WNLSR or the NLSR methods, but for five subjects the LLSR method gave poor fits. There was a non-significant tendency towards longer half lives with higher initial U-Hg. About three years after the cessation of occupational exposure a mobilisation test with 2,3-dimercaptopropane-1-sulphonate (DMPS) was performed on seven subjects. Excretion of $\mathrm{Hg}$, copper $(\mathrm{Cu})$, and zinc ( $\mathrm{Zn}$ ) in urine was estimated before and after the ingestion of $300 \mathrm{mg}$ of DMPS. Treatment with DMPS increased 24 hour urinary excretion by a factor of 7.6 for $\mathrm{Hg}, 12$ for $\mathrm{Cu}$, and 1.5 for $\mathrm{Zn}$. The relative increase in $\mathrm{U}-\mathrm{Hg}$ was not significantly higher than that obtained in a previous study of an occupationally unexposed group. A major proportion (62\%) of $\mathrm{Hg}$ excreted during 24 hours after DMPS appeared in the first six hours. For $\mathrm{Hg}$ and $\mathrm{Zn}$, but not for $\mathrm{Cu}$, the amounts excreted before and after DMPS were highly correlated. The excretion of $\mathrm{Hg}$ in urine probably reflects the amount of $\mathrm{Hg}$ stored in the kidneys; and the use of a single dose of DMPS gives no further information about the size of that pool.
\end{abstract}

(Occup Environ Med 1994;51:337-342)

When an individual has been exposed to inorganic mercury $(\mathrm{Hg})$, urine and faeces are the principal routes of elimination. ${ }^{12}$ In volunteers exposed to radioactive $\mathrm{Hg}$ vapour, faecal excretion dominated in the first week. ${ }^{3}$ After long term exposure, however, urinary excretion seems to predominate. ${ }^{2}$ The kinetic pattern of urinary $\mathrm{Hg}$ excretion has been studied after short term ${ }^{45}$ and long term ${ }^{6-8}$ occupational exposure. The half life for elimination of $\mathrm{Hg}$ in urine was 40-60 days after both short term high $^{45}$ and long term low level exposure. ${ }^{6}$ After long term high exposure it was 70-90 days. ${ }^{78} \mathrm{~A}$ similar result was found in a mixed group of workers exposed both short term and long term. ${ }^{9}$ In two of the studies, ${ }^{47}$ the data indicated that elimination could be described by a two compartment model. As the total number of subjects studied was small, further studies on the elimination kinetics of $\mathrm{U}-\mathrm{Hg}$ were considered desirable.

The main sites of deposition after inhalation of $\mathrm{Hg}$ vapour are the kidneys, the liver, and the brain. ${ }^{12}$ Chelating agents have been used for many years for treatment of metal poisoning. ${ }^{1011}$ In rats exposed to inorganic $\mathrm{Hg}$ the amount of $\mathrm{Hg}$ excreted in urine after a single dose of 2,3-dimercaptopropane-1sulphonate (DMPS) or 2,3-dimercaptosuccinic acid (DMSA) is a good indicator of the renal burden of mercury. ${ }^{12} 13$ These two chelators also increased the excretion of copper $(\mathrm{Cu})$ and zinc $(\mathrm{Zn})^{10}$ and have been used for the mobilisation of $\mathrm{Hg}$ in workers with current exposure to inorganic $\mathrm{Hg}^{814}$ and in persons with and without amalgam fillings. ${ }^{14-17}$ If, in workers previously exposed long term, the increase in $\mathrm{Hg}$ excretion induced by chelating agents a long time after the end of mercury exposure, is much higher than in other subjects with the same baseline $\mathrm{Hg}$ excretion, this could indicate the existence of compartment(s) with slow turnover rates. Such data are scarce, however. ${ }^{818}$ In the present study, a mobilisation test with DMPS was performed in workers about three years after they ceased occupational exposure. Besides $\mathrm{Hg}, \mathrm{Cu}$ and $\mathrm{Zn}$ excretion in urine were also estimated.

\section{Subjects and methods}

ESTIMATION OF MERCURY ELIMINATION HALF LIVES Twelve workers from two different chloralkali plants, all exposed to $\mathrm{Hg}$ vapour, volunteered for multiple consecutive urine sampling, in conjunction with change of employment or retirement. The workers were recruited during a four year period. They had been working in the chloralkali industry for two to 18 (median five) years, and were 22 to 65 years of age at the start of investigation. They were all healthy and had low or moderate alcohol consumption. Table 1 shows their ages, expo- 
Table 1 Previous exposure and background factors in the study group of 12 former chloralkali workers exposed to $\mathrm{Hg}$ vapour

\begin{tabular}{|c|c|c|c|c|c|c|c|}
\hline $\begin{array}{l}\text { Subject } \\
\text { No }\end{array}$ & Age & $\begin{array}{l}\text { Exposure time } \\
(y)\end{array}$ & $\begin{array}{l}\text { Cumulative } \\
\text { exposure index } \\
\text { (nmol.y. } 1^{-1} \text { ) }\end{array}$ & $\begin{array}{l}\text { Fish consumption } \\
\text { (meals/week) }\end{array}$ & Smoking & $\begin{array}{l}\text { No of } \\
\text { amalgam surfaces }\end{array}$ & $\begin{array}{l}\text { Mobilisation test } \\
\text { with DMPS }\end{array}$ \\
\hline $\begin{array}{r}1 \\
2 \\
3 \\
4 \\
5 \\
6 \\
7 \\
8 \\
9 \\
10 \\
11 \\
12\end{array}$ & $\begin{array}{l}57 \\
28 \\
65 \\
26 \\
31 \\
31 \\
27 \\
23 \\
22 \\
33 \\
43 \\
27\end{array}$ & $\begin{array}{c}2 \\
6 \\
18 \\
3 \\
12 \\
13 \\
4 \\
2 \cdot 5 \\
2 \\
4 \\
10 \\
7\end{array}$ & $\begin{array}{r}130 \\
350 \\
830 \\
200 \\
920 \\
950 \\
140 \\
320 \\
170 \\
410 \\
1010 \\
780\end{array}$ & $\begin{array}{r}<1 \\
1 \\
1 \\
1 \\
<1 \\
1 \\
1 \\
1 \\
2 \\
2 \\
1 \\
<1\end{array}$ & $\begin{array}{l}\text { No } \\
\text { Yes } \\
\text { Yes } \\
\text { No } \\
\text { Yes } \\
\text { Yes } \\
\text { No } \\
\text { No } \\
\text { Yes } \\
\text { Yes } \\
\text { Yes } \\
\text { Yes }\end{array}$ & $\begin{array}{r}12 \\
31 \\
0 \\
28 \\
36 \\
34 \\
14 \\
17 \\
15 \\
22 \\
35 \\
26\end{array}$ & $\begin{array}{l}\text { No } \\
\text { Yes } \\
\text { No } \\
\text { Yes } \\
\text { No } \\
\text { Yes } \\
\text { No } \\
\text { Yes } \\
\text { Yes } \\
\text { Yes } \\
\text { No } \\
\text { Yes }\end{array}$ \\
\hline
\end{tabular}

*Integrating $\mathrm{B}-\mathrm{Hg}$ as a function of time.

sure times, smoking habits, fish consumption, and number of amalgam surfaces. The first sampling took place within the first week after the end of exposure for five of the subjects (Nos 4, 5, 7, 9, and 10), within the first three weeks for four subjects (Nos 1, 2, 6, and 8), and after 1.5 to two months for the remaining three subjects (Nos 3, 11, and 12).

First morning urine samples, generally on two or three consecutive days, were taken at several (median nine, range 5-15) occasions during a period of four to 68 (median 28) months. One person was followed for four months only (subject No 5), as he was reemployed at the chlorakali factory after that period. The total number of urine samples collected from each subject varied between 12 and 29.

The urine samples were collected at home in polyethylene bottles (with a small amount of sulphamic acid added) that had previously been washed in RBS 25 detergent. The samples were stored, firstly, in refrigerators for no more than three days, and then at $-25^{\circ} \mathrm{C}$ until analysis. In urine, bacterial growth can cause evaporation of metallic $\mathbf{H g},{ }^{19}$ but addition of sulphamic acid produces stable urine samples for at least one month even at room temperature..$^{20}$ In urine samples stored at low temperatures, $\mathrm{Hg}$ is concentrated in the precipitate, and urine samples were therefore homogenised by vigorous shaking before analysis. From our experience, no loss of $\mathbf{H g}$ occurs in urine samples refrigerated for several months.

Urinary $\mathrm{Hg}$ concentrations $(\mathrm{U}-\mathrm{Hg}$ ) were determined by the cold vapour atomic absorption technique. ${ }^{2021}$ The detection limit was $1 \mathrm{nmol} / 1$. Each sample was analysed in duplicate. Precision was about $95 \%$ for $\mathrm{U}-\mathrm{Hg}$ in the range 5-500 $\mathrm{nmol} / 1$. The accuracy was checked by analysing external reference samples (Lanonorm metals 1, Behring Institute, Behringwerke AB, Marburg and Seronorm batch 108, Nycomed, Oslo, Norway) together with the test samples. The results $(46 \mathrm{nmol} / 1$ (SD 2.6, $\mathrm{n}=14$ ) and $252 \mathrm{nmol} / \mathrm{l}(\mathrm{SD} 7 \cdot 3, \mathrm{n}=$ 10)) were in accordance with the recommended values of $48 \mathrm{nmol} / /$ and $254 \mathrm{nmol} / 1$ respectively. Concentration of $\mathrm{Hg}$ in urine was expressed per mmol creatinine to correct for differences in urinary flow rate. Creatinine was determined with a modified kinetic Jaffé method. Precision, as calculated from duplicate analyses, was greater than $98 \%$.

A cumulative exposure index (table 1) was calculated for each subject from previous concentrations of $\mathbf{H g}$ in blood $(\mathrm{B}-\mathrm{Hg})$, measured in the period between 1970 and the end of exposure, by integrating $\mathrm{B}-\mathrm{Hg}$ as a function of exposure time.

In each subject, models with one or two compartments were fitted to the decrease in $\mathrm{U}-\mathrm{Hg}$, assuming an exponential decrease, by NLSR (non-linear least squares regression). This was done with the NLIN procedure in the SAS statistical program. ${ }^{22}$ Also, all 12 individual curves were analysed simultaneously, calculating the best fit, on the assumption that all subjects had a common half life. This was done with a special version of the EXPFIT program, ${ }^{23}$ EXPGRF17. These different models were compared statistically with the $F$ test for differences in sums of squares. ${ }^{23}$ For the one compartment model, we also used a weighted, non-linear least squares (WNLSR) method, ${ }^{24}$ with the assumption that the variances are proportional to the concentration of $\mathrm{U}-\mathrm{Hg}$ (applicable for $\mathrm{U}-\mathrm{Hg}$ above $1 \mathrm{nmol} / \mathrm{mmol}$ creatinine). The data were also fitted to a linear least squares regression (LLSR) method after log transformation of the U-Hg data (REG procedure in SAS).

When calculating the half lives, a baseline concentration was subtracted from each U$\mathrm{Hg}$. The baseline values were from the average concentration after at least one year of follow up for $\mathbf{1 0}$ of the subjects. If the half life is about two months for $\mathrm{U}-\mathrm{Hg}$ elimination, then a one year period would be enough to reach a baseline concentration. The low concentrations (median 0.8 (range $0.3-1.6$ ) $\mathrm{nmol} / \mathrm{mmol}$ creatinine) in comparison with other occupationally unexposed groups in Sweden, indicate that they had reached their baseline. For two subjects (Nos 1 and 5), who were followed up for four and 10 months only (presumably too short to reach baseline concentrations), we used the median $\mathrm{U}-\mathrm{Hg}$ found in an occupationally unexposed reference group from one of the plants, $1.7 \mathrm{nmol} / \mathrm{mmol}$ creatinine $(n=44)$. A reduction of the baseline concentration by $50 \%$ for these two subjects only slightly increased the point estimate of the half life for the group. For correlations between two variables, Pearson's correlation 
coefficient, $r_{p}$ (after log transformation) was calculated.

\section{MOBILISATION TEST WITH DMPS}

Seven men in the $\mathrm{U}-\mathrm{Hg}$ elimination study (table 1) volunteered for an $\mathrm{Hg}$ mobilisation test with DMPS 18-56 (median 34) months after exposure had ceased. All participants were in good health and had no renal disease. Their body weights varied between 66 and 96 $\mathrm{kg}$. The protocol of the DMPS study was approved by the Board for Medical Ethics of the University of Göteborg and by the National Board of Health and Welfare, Department of Drugs.

One morning sample and two consecutive 24 hour urine samples were collected in metal-free polyethylene bottles. After the first morning urine sample on the first day $(\mathrm{m}$, pre), all urine excreted during the next 24 hours (24h, pre) was collected. After the first 24 hour collection period, the volunteers ingested $300 \mathrm{mg}$ of DMPS before breakfast, and started to collect urine for the second 24 hour period (24h). Urine excreted during the first six hours (6h) after DMPS was collected in a separate bottle. One subject (No 10) misunderstood the instructions and ingested DMPS after the first morning sample. His baseline excretion of $\mathrm{Hg}, \mathrm{Cu}$, and $\mathrm{Zn}$ during $24 \mathrm{~h}$ before the mobilisation test was therefore calculated from the excretion rate in the first morning sample.

For the fixed term samples, the volume and the time limits were registered. Storage and determination of $\mathrm{U}-\mathrm{Hg}$ and creatinine were the same as described earlier. Urinary $\mathrm{Zn}$ was analysed by flame atomic absorption. One $\mathrm{ml}$ $0.3 \mathrm{M}$ nitric acid was added to one $\mathrm{ml}$ urine, and absorbance was measured at $215 \mathrm{~nm}$. Urinary $\mathrm{Cu}$ was analysed by graphite furnace atomic absorption at $324.8 \mathrm{~nm}$. Urine samples were diluted (1:5) with Triton solution including ammonium nitrate $(0 \cdot 12 \mathrm{~mol} / \mathrm{l})$ as a modifier. Urine, spiked with $\mathrm{Zn}$ or $\mathrm{Cu}$, was used for calibration. Each sample was analysed in duplicate. The detection limit for $\mathrm{Cu}$ was $0.1 \mu \mathrm{mol} /$, and for $\mathrm{Zn} 1.0 \mu \mathrm{mol} / \mathrm{l}$. Precision was above $95 \%$ for $\mathrm{U}-\mathrm{Zn}$ concentrations in the range $3-30 \mu \mathrm{mol} / 1$ and about $95 \%$ for $\mathrm{U}-\mathrm{Cu}$ in the range $0 \cdot 1-5 \mu \mathrm{mol} / \mathrm{l}$. Quality control with a reference sample of lyophilised urine (Seronorm batch 108, Nycomed, Oslo, Norway) measured together with the samples, showed good accuracy. The results for U-Zn $(9.9 \mu \mathrm{mol} / 1$ (SD $0.2, \mathrm{n}=14)$ and $\mathrm{U}-\mathrm{Cu}(721$ $\mathrm{nmol} / \mathrm{l}(\mathrm{SD}=40, \mathrm{n}=18)$ ), accorded with the certified values of $10 \mu \mathrm{mol} / \mathrm{l}$ and $709 \mathrm{nmol} / \mathrm{l}$.

For correlations between two variables Pearson's correlation coefficient $r_{\mathrm{p}}$ (after log transformation) was calculated.

\section{Results}

MERCURY ELIMINATION HALF LIVES

Table 2 shows the results from fitting a one compartment model to individual $\mathrm{U}-\mathrm{Hg}$ data with different regression methods. When the NLSR method was used for each subject, the median half life was 59 days. From a model with a common half life (EXPFIT), the point estimate was 69 days. For four subjects this model gave a skewed distribution of residuals over time. The model with individual half lives was statistically better $(F$ test, $\mathrm{p}=0.02$ ) than the model with a shared half life.

The weighted non-linear method (WNLSR) with variances assumed proportional to concentration, resulted in $R^{2}$ values (the fraction of the variance explained by the model) similar to those obtained with the NLSR method, whereas the LLSR method gave a low $R^{2}$ in several subjects. When the estimated values from the different regression models were visually compared with the data points, the equations from WNLSR for a few subjects seemed to fit the data better than the corresponding equations from NLSR. For most subjects, however, NLSR and WNLSR were equally good. The first fitted the data better for high concentrations and the second better for moderate concentrations. The

Table 2 Kinetics of $\mathrm{Hg}$ in urine $(\mathrm{U}-\mathrm{Hg})$ in 12 men after occupational exposure

\begin{tabular}{|c|c|c|c|c|c|c|c|c|c|}
\hline \multirow[b]{2}{*}{$\begin{array}{l}\text { Subject } \\
\text { No }\end{array}$} & \multicolumn{3}{|l|}{ NLSR } & \multicolumn{3}{|l|}{ WNLSR } & \multicolumn{3}{|l|}{$L L S R$} \\
\hline & $\begin{array}{l}T_{1 / 2} \\
\text { (95\% CI) } \\
\text { (days) }\end{array}$ & $\begin{array}{l}Y_{0} \\
\text { (nmol/mmol } \\
\text { creatinine }\end{array}$ & $\begin{array}{l}R^{2} \\
(\%)\end{array}$ & $\begin{array}{l}T_{1 / 2} \\
\text { (95\% CI) } \\
\text { (days) }\end{array}$ & $\begin{array}{l}Y_{0} \\
\text { (nmol/mmol) } \\
\text { creatinine }\end{array}$ & $\begin{array}{l}R^{2} \\
(\%)\end{array}$ & $\begin{array}{l}T_{1 / 2} \\
\text { (95\% CI) } \\
\text { (days) }\end{array}$ & $\begin{array}{l}Y_{0} \\
\text { (nmol/mmol) } \\
\text { creatinine }\end{array}$ & $\begin{array}{l}R^{2} \\
(\%)\end{array}$ \\
\hline $\begin{array}{r}1 \\
2 \\
3 \\
4 \\
5 \\
6 \\
7 \\
8 \\
9 \\
10 \\
11 \\
12\end{array}$ & $\begin{array}{l}58(47-77) \\
51(45-59) \\
46(39-55) \\
83(66-111) \\
52(41-74) \\
53(40-75) \\
41(34-51) \\
78(67-93) \\
59(45-87) \\
88(76-104) \\
66(51-96) \\
67(58-78)\end{array}$ & \begin{tabular}{r|}
$14 \cdot 9$ \\
$22 \cdot 0$ \\
$20 \cdot 1$ \\
$13 \cdot 1$ \\
$14 \cdot 3$ \\
$14 \cdot 5$ \\
$6 \cdot 1$ \\
$24 \cdot 5$ \\
$37 \cdot 6$ \\
$26 \cdot 4$ \\
$16 \cdot 2$ \\
$32 \cdot 8$
\end{tabular} & $\begin{array}{l}98 \\
99 \\
99 \\
95 \\
98 \\
93 \\
97 \\
98 \\
95 \\
97 \\
96 \\
98\end{array}$ & $\begin{array}{l}57(48-71) \\
46(41-52) \\
47(41-54) \\
82(71-99) \\
48(39-61) \\
52(45-63) \\
40(35-46) \\
63(55-74) \\
63(53-76) \\
79(68-93) \\
59(47-77) \\
54(46-66)\end{array}$ & $\begin{array}{r}14 \cdot 8 \\
22 \cdot 9 \\
19 \cdot 4 \\
12 \cdot 4 \\
14 \cdot 5 \\
13 \cdot 5 \\
6 \cdot 0 \\
26 \cdot 9 \\
35 \cdot 2 \\
26 \cdot 7 \\
17 \cdot 1 \\
39 \cdot 8\end{array}$ & $\begin{array}{l}97 \\
97 \\
99 \\
94 \\
98 \\
93 \\
97 \\
95 \\
95 \\
93 \\
95 \\
91\end{array}$ & $\begin{array}{c}57(50-67) \\
128(92-210) \\
49(44-56) \\
95(87-105) \\
46(39-56) \\
61(55-68) \\
37(33-43) \\
77(61-104) \\
56(51-61) \\
126(103-161) \\
325(203-743) \\
226(134-722)\end{array}$ & $\begin{array}{r}14.9 \\
6.9 \\
18 \cdot 1 \\
11.4 \\
15 \cdot 1 \\
11.8 \\
6.4 \\
18.6 \\
40.5 \\
15.6 \\
4.3 \\
3.4\end{array}$ & $\begin{array}{l}94 \\
63 \\
96 \\
95 \\
91 \\
95 \\
95 \\
76 \\
98 \\
77 \\
52 \\
40\end{array}$ \\
\hline $\begin{array}{l}\text { Median } \\
\text { Mean }\end{array}$ & $\begin{array}{l}59(51-78) \\
62\end{array}$ & & & $\begin{array}{l}55(47-63)^{\star} \\
57\end{array}$ & & & $\underline{-}^{69}(49-128)^{\star}$ & & \\
\hline
\end{tabular}

96\% CI (binomial distribution) ${ }^{33}$

Results from one comparment models using a non-linear least-squares regression method (NLSR), a weighted non-linear leastsquares regression method (WNLSR), and a linear least-squares regression method (LLSR). After subtraction of the estimated baseline level, the following equations were fitted: $U-H g=Y_{0}^{\star} e^{-t c}\left(N L S R\right.$ and $\left.W_{N L S R}\right)$ and $\ln \left(U-H_{g}\right)=\ln \left(Y_{0}\right)-b t(L L S R)$. The half lines $\left(T_{12}\right)$ are derived from: $T_{12}=\operatorname{In} 2 / b . R^{2}$ is the fraction of the variance in U-Hg explained by the model. Confidence intervals $(95 \% \mathrm{CD})$ are calculated as \pm 2 SE (asymptotic standard error). 


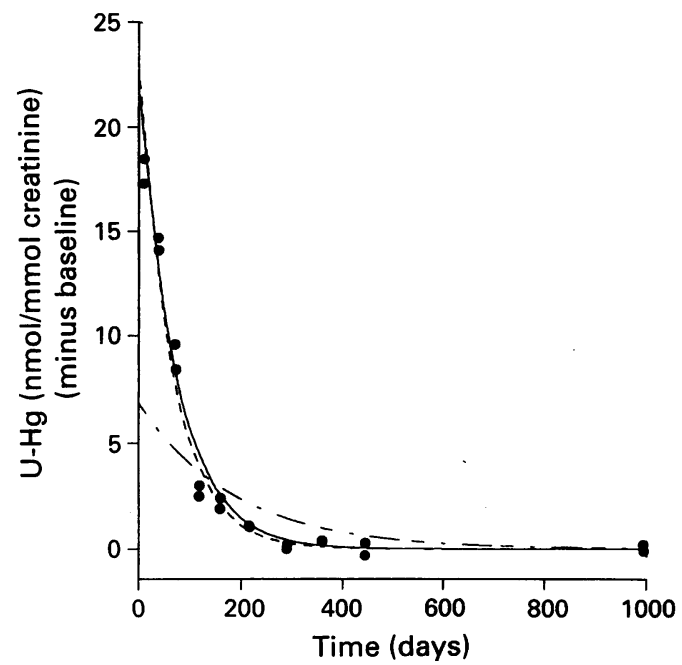

Elimination of $\mathrm{Hg}$ in urine after long term exposure to $\mathrm{Hg}$ vapour (subject No 2). The observed

data are compared with the predicted one compartment equations from different regression methods.

( $-N L S R$ (non-linear least squares regression); ----WNLSR (weighted non-linear least squares regression); - - LLSR (linear least squares regression)) after log transformation.

median half life with the WNLSR method, 55 days, was somewhat lower compared with that obtained with the NLSR method. The median point estimate for the half life with the LISR method was 69 days. The LLSR method gave very poor estimates of the half lives and intercepts $\left(Y_{0}\right)$ for five subjects (Nos $2,8,10,11$ and 12). The figure shows the poor fit to the observed values with the LLSR method for subject No 2 .

There were no significant correlations between the half life estimates from the one compartment model (NLSR) on the one hand and exposure time, cumulative exposure index, or the calculated $\mathrm{U}-\mathrm{Hg}\left(\mathrm{Y}_{0}\right)$ at the end of exposure on the other. There was, however, a tendency towards longer half lives with higher intercepts $\left(r_{\mathrm{p}}=0.46\right)$ and shorter exposure time $\left(r_{\mathrm{p}}=-0 \cdot 41\right)$. The results were similar when WNLSR half life estimates were used.

When the data were fitted to a two compartment model, a fast phase was discerned in three of the subjects. The half life estimates for the fast and slow phases were $1 \cdot 6,3 \cdot 2$, and 8.9 days and 53,83 , and 66 days respectively. For these subjects, the two compartment model was not significantly better than the corresponding one compartment model. No second compartment could be shown with the common half life model (EXPFIT).

The average intraindividual variation of $\mathrm{U}-\mathrm{Hg}$ in morning samples on consecutive days was $36 \%$ (coefficient of variation for morning samples corrected for creatinine) in the interval of $0 \cdot 1-2 \mathrm{nmol} / \mathrm{mmol}$ creatinine, $19 \%$ for $2 \cdot 1-9.9 \mathrm{nmol} / \mathrm{mmol}$ creatinine, and $13 \%$ for $10-25 \mathrm{nmol} / \mathrm{mmol}$ creatinine.

\section{MOBILISATION TEST WITH DMPS}

Table 3 shows $\mathrm{U}-\mathrm{Hg}$ values in urine before and after the DMPS mobilisation test. After the ingestion of DMPS (dose $3.0-4.5 \mathrm{mg} / \mathrm{kg}$ ), the excretion of $\mathrm{U}-\mathrm{Hg}$ increased. Of the amount of mercury excreted during 24 hours after DMPS most appeared in the first 6 hour sample (mean $62 \%$, range $36 \%-78 \%$ ). The average of the individual ratios $\mathrm{U}-\mathrm{Hg}(24 \mathrm{~h}) /$ $\mathrm{U}-\mathrm{Hg}(\mathrm{m}$, pre) and $\mathrm{U}-\mathrm{Hg}(24 \mathrm{~h}) / \mathrm{U}-\mathrm{Hg}(24$, pre) were 6.8 and 7.6 respectively. The ratio was expressed in these two ways to make comparisons with other studies ${ }^{814-17}$ possible. The U-Hg (24h) was significantly correlated with $\mathrm{U}-\mathrm{Hg}$ (m, pre). The Pearson correlation coefficient was $0 \cdot 79$. There was also a high correlation between the U-Hg (24 h) (in $\mu \mathrm{g}$ ) before and after the DMPS test $\left(r_{\mathrm{p}}=0.86\right)$.

The rate of urinary excretion of $\mathrm{Cu}$ and $\mathrm{Zn}$ also increased (table 4). The average ratios between the amounts excreted in the 24 hour sample after and before the ingestion of DMPS respectively, was 12 for $\mathrm{Cu}$ and 1.5 for Zn (one outlier excluded, see table 4). The proportion of the amount excreted during the first six hours was $51 \%$ for $\mathrm{Cu}$ and $42 \%$ for $\mathrm{Zn}$. There were no significant correlations between the $\mathrm{Cu}$ excretion before and after DMPS. Both U-Zn (6h) and U-Zn (24h) correlated significantly $(p<0.001)$ with the amount excreted 24 hours before the DMPS test $\left(r_{\mathrm{p}}=0.96\right.$ and 0.99 respectively).

About a fourfold increase in 24 hour albumin excretion was seen in one subject after the ingestion of DMPS. The concentration, however, returned to normal on the next day. In the other six subjects no such effect was seen. Two subjects reported headaches after the ingestion of DMPS.

\section{Discussion}

KINETICS OF MERCURY IN URINE

The elimination of $\mathrm{Hg}$ in urine was well characterised by a one compartment model. Our point estimate for the half life was 55 days

Table $3 \mathrm{Hg}$ concentrations determined in morning urine $(\mathrm{U}-\mathrm{Hg})$ (m, pre)) and 24 hour urine before (U-Hg (24h, pre)), and urine 0-6 hours (U-Hg (6h)), and 0-24 hours (U-Hg (24h)) after ingestion of $300 \mathrm{mg} D M P S$

\begin{tabular}{|c|c|c|c|c|c|c|c|c|c|}
\hline \multirow{2}{*}{$\begin{array}{l}\text { Subject } \\
\text { No }\end{array}$} & \multirow{2}{*}{$\begin{array}{l}\mathrm{U}-\mathrm{Hg}(\mathrm{m}, \mathrm{pre}) \\
\text { nmol/mmol } \\
\text { creatinine }\end{array}$} & \multirow{2}{*}{$\begin{array}{l}U-H g(6 h) \\
\text { nmol/mmol } \\
\text { creatinine }\end{array}$} & \multirow{2}{*}{$\begin{array}{l}\mathrm{U}-\mathrm{Hg}(24 \mathrm{~h}) \\
\text { nmol/mmol } \\
\text { creatinine }\end{array}$} & \multirow{2}{*}{$\frac{U-H g(24 h)}{U-H g(m, p r e)^{\star}}$} & \multirow{2}{*}{$\begin{array}{l}\text { U-Hg } \\
(24 h, p r e) \\
(\mu g)\end{array}$} & \multirow{2}{*}{$\begin{array}{l}U-H g(6 h) \\
(\mu g)\end{array}$} & \multirow{2}{*}{$\begin{array}{l}U-H g(24 h) \\
(\mu g)\end{array}$} & \multirow{2}{*}{$\frac{U-H g(6 h)}{U-H g(24 h(\%))^{*}}$} & \multirow{2}{*}{$\frac{U-H g(24 h)}{U-H g(24 h, p r e)^{*}}$} \\
\hline & & & & & & & & & \\
\hline $\begin{array}{r}2 \\
4 \\
6 \\
8 \\
9 \\
10 \\
12\end{array}$ & $\begin{array}{l}1.5 \\
1.5 \\
3.6 \\
1.7 \\
1.2 \\
1.4 \\
0.9\end{array}$ & $\begin{array}{c}27 \\
13 \\
67 \\
37 \\
\mathbf{4 4} \\
\mathbf{8} \cdot 0 \\
2 \cdot 5\end{array}$ & $\begin{array}{c}12 \\
6 \cdot 3 \\
26 \\
15 \\
14 \\
5 \cdot 3 \\
2 \cdot 6\end{array}$ & $\begin{array}{c}8 \cdot 4 \\
4 \cdot 4 \\
7 \cdot 4 \\
9 \cdot 1 \\
12 \\
3 \cdot 8 \\
2 \cdot 9\end{array}$ & $\begin{array}{l}3 \cdot 4 \\
3 \cdot 8 \\
8 \cdot 9 \\
5 \cdot 8 \\
3 \cdot 0 \\
3 \cdot 4 \dagger \\
1 \cdot 7\end{array}$ & $\begin{array}{c}24 \\
11 \\
65 \\
31 \\
30 \\
6 \cdot 6 \\
2 \cdot 6\end{array}$ & $\begin{array}{c}36 \\
18 \\
82 \\
44 \\
38 \\
15 \\
7 \cdot 3\end{array}$ & $\begin{array}{l}68 \\
62 \\
79 \\
70 \\
78 \\
43 \\
36\end{array}$ & $\begin{array}{c}10 \\
4 \cdot 7 \\
9 \cdot 2 \\
7 \cdot 5 \\
13 \\
4 \cdot 5 \\
4 \cdot 2\end{array}$ \\
\hline Mean & $1 \cdot 7$ & 28 & 12 & $6 \cdot 8$ & $4 \cdot 3$ & 24 & 34 & 62 & $7 \cdot 6$ \\
\hline
\end{tabular}

*The ratio was calculated from original data.

tThe 24 hour excretion was calculated from a presample with shorter sampling time. 
Table $4 \mathrm{Cu}$ and $\mathrm{Zn}$ concentrations in urine as determined before (U-Cu/Zn(24h,pre)) and 0-6 hours (U-Cn/Zn(6h)) or 0-24 hours (U-Cu/Zn(24h)) after ingestion of $300 \mathrm{mg} D M P S$

\begin{tabular}{|c|c|c|c|c|c|c|c|c|}
\hline \multirow{2}{*}{$\begin{array}{l}\text { Subject } \\
\text { No }\end{array}$} & \multirow{2}{*}{$\begin{array}{l}U-C u(24 h, \text { pre }) \\
(\mu g)\end{array}$} & \multirow{2}{*}{$\begin{array}{l}U-C u(6 h) \\
(\mu g)\end{array}$} & \multirow{2}{*}{$\begin{array}{l}U \\
U-C u(24 h) \\
(\mu g)\end{array}$} & \multirow{2}{*}{$\frac{U-C u(24 h)}{U-C u(24 h, \text { pre })^{*}}$} & \multirow{2}{*}{$\begin{array}{l}U-Z n(24 h, p r e) \\
(\mu g)\end{array}$} & \multirow{2}{*}{$\begin{array}{l}U-Z n(6 h) \\
(\mu g)\end{array}$} & \multirow{2}{*}{$\begin{array}{l}U-Z n(24 h) \\
(\mu g)\end{array}$} & \multirow{2}{*}{$\frac{U-Z n(24 h)}{U-Z n(24 h, p r e)^{*}}$} \\
\hline & & & & & & & & \\
\hline $\begin{array}{r}2 \\
4 \\
6 \\
8 \\
9 \\
10 \\
12\end{array}$ & $\begin{array}{l}14 \\
21 \\
13 \\
16 \\
22 \\
14 \dagger \\
13\end{array}$ & $\begin{array}{r}173 \\
48 \\
90 \\
94 \\
95 \\
87 \\
46\end{array}$ & $\begin{array}{l}330 \\
111 \\
148 \\
169 \\
158 \\
159 \\
138\end{array}$ & $\begin{array}{l}24 \\
5 \cdot 4 \\
11 \\
11 \\
7 \cdot 3 \\
12 \\
11\end{array}$ & $\begin{array}{l}759 \\
466 \\
904 \\
926 \\
830 \\
216 \dagger \\
493\end{array}$ & $\begin{array}{l}456 \\
311 \\
631 \\
620 \\
501 \\
180 \\
279\end{array}$ & $\begin{array}{r}1222 \\
744 \\
1324 \\
1361 \\
1163 \\
1303 \\
805\end{array}$ & $\begin{array}{l}1.6 \\
1.6 \\
1.5 \\
1.5 \\
1.4 \\
(6.0) \ddagger \\
1.6\end{array}$ \\
\hline Mean & 16 & 90 & 173 & 12 & 657 & 426 & 1132 & 1.5 \\
\hline
\end{tabular}

*The ratio was calculated from original data.

†The 24hour excretion was calculated from a presample with shorter sampling time.

$\$$ Value in parentheses is not included in the average.

(median, WNLSR method). This point estimate is longer than the median half life reported among long term, low level exposed dental personnel before and after a vacation (41 days). ${ }^{6}$ Three studies of long term, ${ }^{78}$ or mixed $^{9}$ high level exposed workers, have shown longer half lives, of about 70 to 90 days. There is, however, large interindividual variation in all studies.

In the present study, there was a tendency towards longer half lives with higher initial $\mathrm{U}-\mathrm{Hg}$ concentrations $\left(\mathrm{Y}_{0}\right)$. This tendency was more obvious when our data were compared with the half life estimates in other studies of long term exposed workers. In a study of dental personnel, the starting values were about $3 \mu \mathrm{g} / \mathrm{g}$ creatinine, and the half life 41 days. ${ }^{6}$ In workers from an alkaline battery factory, the initial concentrations were about $200 \mu \mathrm{g} / \mathrm{g}$ creatinine and the half life was 90 days. ${ }^{8}$ In the present study, the initial concentrations were about $35 \mu \mathrm{g} / \mathrm{g}$ creatinine $(20 \mathrm{nmol} / \mathrm{mmol}$ creatinine) and the half life 55 days.

We found no significant correlations between the half life estimates and exposure time or the cumulative exposure index. As only one or two B-Hg samples were taken each year and $\mathrm{B}-\mathrm{Hg}$ is influenced by recent exposure, our exposure index is a relatively crude estimate. There was a tendency towards longer half lives with shorter exposure time. An induction of a higher metabolic rate after a longer exposure time would result in such an association, but there is no evidence of such an effect.

The indications of a fast compartment in a few subjects were relatively weak. Nor was a fast phase for U-Hg seen in a previous study of chloralkali workers during a vacation period. ${ }^{25}$ Piotrowski et al reported a fast elimination phase of about two days in three subjects, but the methods were crude. We have found two elimination phases after brief exposure, ${ }^{4}$ but the peak $\mathrm{U}-\mathrm{Hg}$, in accordance with the results of another recent study, ${ }^{26}$ occurred several weeks after the end of exposure. The excretion pattern after short term exposure seems to be different from that after long term exposure (when uptake and elimination have reached a steady state).

Some data indicate that the $\mathrm{Hg}$ concentrations in the kidneys and brains of workers formerly exposed to $\mathrm{Hg}$ are still substantially raised many years after the end of exposure. ${ }^{27-30}$ If this were the case in our subjects, the reason we did not see a slower elimination phase is probably that there is a rather limited amount of $\mathrm{Hg}$ in these pools or a very slow elimination rate, or both.

There were no large differences in the half life estimates given by the WNLSR or the NLSR methods, although the first seems to fit data better for a few subjects. Calculation of the variances in different concentration intervals indicates a concentration dependent variance. Therefore, in our case, the WNLSR method is the method of choice from a theoretical point of view. ${ }^{24}$ The LLSR method resulted in models with bad fits for five subjects. The problems with LLSR arise mainly when subjects are followed up over such a long period that they reached very low concentrations. The LLSR method tends to give too much weight to slight absolute differences (but high differences in log transformed values) between observed and predicted concentrations.

METAL EXCRETION AFTER DMPS TEST

It was hoped that the mobilisation test with DMPS would give some information on the compartmentalisation of $\mathrm{Hg}$. This did not happen. The relative increase in $\mathrm{U}-\mathrm{Hg}$ after the mobilisation test, 6.8 (SD 3.2), was in agreement $(p=0 \cdot 20$, Student's $t$ test) with the ratio of $5.3(\mathrm{SD} 2.4, \mathrm{n}=18)$ found in a previous study of an occupationally unexposed control group. ${ }^{14}$ The same result was obtained when the doses in mg per kg body weight were used in the calculation. This indicates that if a slow compartment exists, this must be very small, or that a single dose of DMPS cannot mobilise $\mathrm{Hg}$ from pools with a slow turnover rate.

The high proportion of the total amount of $\mathrm{Hg}$ excreted in urine during the first six hours $(62 \%)$ accords with results presented previously. ${ }^{14}$ Similar results have also been reported in humans after a single dose of DMSA. ${ }^{8}$ As in other studies with DMSA after occupational exposure had stopped, ${ }^{58}$ or with DMPS during ongoing exposure, ${ }^{14} 17$ a high correlation was found between the excretion of $\mathrm{Hg}$ in urine before and after a single dose. In summary, the excretion of $\mathrm{Hg}$ in urine probably reflects the amount of $\mathrm{Hg}$ stored in the kidneys, and the use of a single dose of chelating agents, such as DMPS or DMSA, gives no further information about the size of that pool. This conclusion has also been reached by others. ${ }^{814} 17$ The extra $\mathrm{Hg}$ excreted after a single dose of DMPS is equivalent to 
the amount normally excreted during a week.

In rats, the rate of removal from the kidneys was higher after DMPS than after an equimolar dose of DMSA. ${ }^{13}$ This also seems to be true for humans, because a dose of $\mathbf{3 0 0}$ mg DMPS caused a fivefold to eightfold increase in $\mathrm{U}-\mathrm{Hg}$, both in previously occupationally exposed subjects (this study) and in occupationally unexposed groups, ${ }^{14} 1517$ whereas only about a twofold increase was obtained after 2 g DMSA. ${ }^{8}$

The increased excretion of $\mathrm{Cu}$ and $\mathrm{Zn}$ in urine after a single dose of DMPS accords with results from animal experiments. ${ }^{10}$ The greatest effect seems to be on $\mathrm{Cu}$ excretion, where a 13-fold increase has been reported after two days of treatment of $\mathbf{H g}$ exposed workers with DMPS. ${ }^{10}$ In animals, the effect on $\mathrm{Cu}$ and $\mathrm{Zn}$ is dose dependent and returns to normal if the drugs are withdrawn. ${ }^{10}$ Excretion of $\mathrm{Zn}$ after DMPS in humans has not been reported previously. In humans, the elimination of $\mathrm{Cu}$ is mainly via the bile, and only a few $\%$ is found in the urine, usually about $20 \mu \mathrm{g} /$ day. $^{31}$ In our group, the average excretion of $\mathrm{Cu}$ before DMPS was $16 \mu \mathrm{g} /$ day. The major route of elimination of $\mathrm{Zn}$ is via the gastrointestinal tract $(75 \%)$, and the rest via urine. ${ }^{32}$ The excretion in humans is about 0.5 $\mathrm{mg}$ /day, which is similar to the average 0.7 $\mathrm{mg} /$ day found in our group. The extra loss of $\mathrm{Cu}$ and $\mathrm{Zn}$ after a single dose of DMPS seems to be small compared with the total normal elimination.

We are grateful to Associate Professor Bengt Järvholm for his valuable comments on this manuscript and the staff at the Department of Clinical Chemistry, Sahlgren's University Hospital, for the analysis of copper, zinc, and creatinine. The Swedish Medical Research Swedish Medical Research Council, the Swedish Environmental Protection Agency, the Swedish Work Environment Fund, the Swedish Medical Society, the Medical Göteborg and Lund, and the Swedish Society for Medical Göteborg and Lund, and the Swedish
Research have provided financial support.

1 World Health Organisation. Environmental health criteria 118. Inorganic mercury. Geneva: WHO, 1991.

2 Clarkson TW, Hursh JB, Sager PR, Syversen TLM. Mercury. In: Clarkson TW, Friberg L, Nordberg GF, Sager PR, eds. Biological monitoring of toxic metals. New York, NY: Plenum Press 1988:199-246.

3 Cherian MG, Hursh JB, Clarkson TW, Allen J Radioactive mercury distribution in biological fluids and excretion in human subjects after inhalation of mercury vapour. Arch Environ Health 1978;33:109-14.

4 Barregård L, Sällsten G, Schüt A, Attewell R, Skerfving $S$, Järvholm $B$. Kinetics of mercury in blood and urine after brief occupational exposure. Arch Environ Health after brief occupati

5 Bluhm R, Bobbitt R, Welch L, Wood AJ, Bonfiglio JF, Sarzen C, et al. Elemental mercury vapour toxicity, treatment, and prognosis after acute, intensive exposure
in chloralkali plant workers. Part I: History, neuropsyin chloralkali plant workers. Part I: History, neuropsychological finding

6 Skare I, Engqvist A. Urinary mercury clearance of dental personnel after a long term intermission in occupational exposure. Swed Dent $f$ 1990;14:255-9.

7 Piotrowski J, Trojanowska B, Mozilnicka EM. Excretion kinetics and variability of urinary mercury in workers exposed to mercury vapor. Int Arch Occup Environ Health 1975;35:245-56.

8 Roels HA, Boeckx M, Ceulemans E, Lauwerys RR Urinary excretion of mercury after occupational expo- sure to mercury vapour and influence of the chelating agent meso-2,3-dimercaptosuccinic acid (DMSA). $\mathrm{Br} \mathcal{F}$ Ind Med 1991;48:247-53.

9 Ellingsen D, Thomassen $Y$, Kjuus $H$. Urinutskilling av kvikksolv etter opphort eksponering for kvikksolvdamp i en kloralkali fabrik. (In Norwegian). Abstract. 41 Nordiska Arbetsmiljomotet 1992:42.

10 Aposhian V. DMSA and DMPS - water soluble antidotes for heavy metal poisoning. Ann Rev Pharmacol Toxicol 1983;23:193-215.

11 Aaseth J. Recent advances in therapy of metal poisonings with chelating agents. Human Toxicoloog 1983;2:257-72.

12 Cherian MG, Miles EF, Clarkson TW, Cox C. Estimation of mercury burdens in rats by chelation with dimercaptopropane sulfonate. $\mathcal{F}$ Pharmacol Exp Ther 1988;245: topropane

13 Buchet JP, Lauwerys RR. Influence of 2,3 dimercaptopropane-1-sulfonate and dimercaptosuccinic acid on the mobilization of mercury from tissues of rats pretreated with mercuric chloride, phenylmercury acetate or mercury vapors. Toxicology 1989;54:323-33.

14 Molin M, Schütz A, Skerfving S, Sällsten G. Mobilized mercury in subjects with varying exposure to elemental mercury vapour. Int Arch Occup Environ Health 1991; 63:187-92.

15 Hickel R, Meier C, Schiele R, Raab W, Petschelt A. Nebenwirkungen von amalgam? Eine interdisziplinäre Studie. Dtsch Zahn Mund Kieferheilkd Zentralb 1991;46: 542-4.

16 Aposhian HV, Bruce DC, Alter W, et al. Urinary mercury after administration of 2,3-dimercaptopropane-1sulfonic acid: correlation with dental amalgam score. FASEB $\%$ 1992;6:2472-6.

17 Zander D, Ewers U, Freier I, Blockhaus A. Untersuchungen zur Quecksilberbelastung der Bevölkerung III. Quicksilbermobilisation durch DMPS

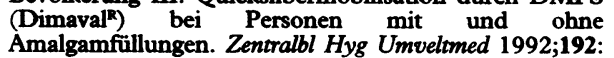
447-54.

18 He FS, Zhow XR, Lin BX, Xiung YP, Chen SY, Zhang SL, Ru JU, Deng MH. Prognosis of mercury poisoning in mercury refinery workers. Annals of the Academy of Medicine Singapore 1984;13(suppl):389-93.

19 World Health Organisation. Envirommental health criteria 1 Mercury. Geneva: WHO, 1976.

20 Skare I. Microdetermination of mercury in biological samples. Part III: Automated determination of mercury in urine, fish and blood samples. Analyst 1972;97:148-55.

21 Einarsson Ō, Lindstedt G, Bergström T. A computerized automatic apparatus for determination of mercury in biological samples. Fourmal of Automatic Chemistry 1984; 6:74-9.

22 SAS Institute Inc. SAS/STAT Guide for personal computers version 6 edition. Cary, NC: SAS Institute Inc, 1987 675-712.

23 Guardabasso V, Munson PJ, Rodbard D. EXPFIT: a program for simultaneous analysis of families of exponential decay curves. Computer Methods and Programs in Biomedicine 1988;27:55-63.

24 Bailer AJ, Portier CJ. A note on fitting one-compartment models: Non-linear least squares versus linear least models: Non-linear least squares versus linear leas squares using

25 Sällsten G, Barregård L, Schütz A. Decrease in mercury concentration in blood after long term exposure: kinetic study of chloralkali workers. $\mathrm{Br} \mathscr{\mathrm { F }}$ Ind $M e$ 1993;50:814-21.

26 Molin M, Bergman B, Marklund SL, Schütz A. Mercury, selenium, and glutathione peroxidase before and after amalgam removal in man. Acta Odontal Scand 1990 48:109-22.

27 Kosta L, Byrne AR, Zelenko V. Correlation between selenium and mercury in man following exposure to inorganic mercury. Nature 1975;254:238-9.

28 Hargreaves RJ, Evans JG, Janota I, Magos L, Cavanagh JB. Persistent mercury in nerve cells 16 years after metallic mercury poisoning. Neuropathol Appl Neurobiol metallic mercury

29 Nylander $M$, Weiner J. Mercury and selenium concentrations and their inter-relationships in organs from dental staff and the general population. Br f Ind Med 1991 48:729-34.

30 Takahata $\mathrm{N}$, Hideo $\mathrm{H}$, Watanabe $\mathrm{S}$, Anso $T$ Accumulation of mercury in the brains of two autopsy cases with chronic inorganic mercury poisoning. Folia
Psychiatrica et Neurologica faponica 1970;24:59-69.

31 Aaseth J, Norseth T. Copper. In: Friberg L, Nordberg GF Vouk V, eds. Handbook on the toxicology of metals, 2nd ed. Amsterdam: Elsevier, 1986:233-54.

32 Elinder C-G. Zinc. In: Friberg L, Nordberg GF, Vouk K eds. Handbook on the toxicology of metals, 2nd ed. Amsterdam: Elsevier 1986:664-79.

33 Gardner MJ, Altman DG. Statistics with confidence. London: British Medical Journal, 1989. 